\title{
Changes in morpho-physiological attributes of Eucalyptus globulus plants in response to different drought hardening treatments
}

Rafael E. Coopman*

Departamento de Silvicultura

Facultad de Ciencias Forestales y

Departamento de Botánica

Facultad de Ciencias Naturales y Oceanográficas

Universidad de Concepción

Victoria 631, Barrio Universitario

Casilla 160-C

Concepción, Chile

Tel: 560412204115

Fax: 560412254224

E-mail: rcoopman@udec.cl

\section{Jorge C. Jara}

Departamento de Recursos Hídricos

Facultad de Ingeniería Civil Agrícola

Universidad de Concepción

Avenida Vicente Méndez 592

Chillán, Chile

Tel: 56042208851

Fax: 56042275303

E-mail: jcjara@udec.cl

\section{Leon A. Bravo}

Departamento de Botánica

Facultad de Ciencias Naturales y Oceanográficas

Universidad de Concepción

Barrio Universitario $\mathrm{s} / \mathrm{n}$

Casilla 160-C

Concepción, Chile

Tel: 560412204115

Fax: 560412254224

E-mail: lebravo@udec.cl

\section{Katia L. Sáez}

Departamento de Estadística

Facultad de Ciencias Físicas y Matemáticas Universidad de Concepción

Avenida Esteban Iturra s/n, Barrio Universitario Casilla 160-C

Concepción, Chile

Tel: 560412204554

Fax: 560412251529

E-mail: ksaez@udec.cl

Gloria R. Mella

Departamento de Silvicultura

Facultad de Ciencias Forestales

Universidad de Concepción

Victoria 631, Barrio Universitario

Casilla 160-C

Concepción, Chile

Tel: 56412204092

Fax: 56412255164

\section{Rene Escobar}

Departamento de Silvicultura

Facultad de Ciencias Forestales

Universidad de Concepción

Victoria 631, Barrio Universitario

$$
\text { Casilla 160-C }
$$

Concepción, Chile

Tel: 56412204092

Fax: 56412255164 
Financial support: Received from the company Forestal Arauco S.A. Grant INNOVA BIO-BIO 03-B1-210-L1 and grant MECESUP, UCO 0214.

Keywords: freezing resistance, root growth potential, stem xylem water potential, water stress, water relationships.

Abbreviations: e: volumetric module of elasticity

$\Psi \pi_{\mathrm{tlp}}$ : osmotic potential at the turgor loss point

$\Psi \pi_{\text {sat }}$ : saturation osmotic potential

$\Psi_{\text {pd }}:$ Predawn stem xylem water potential

$\Psi_{\text {sxtw }}:$ stem xylem total water potential

ARL: the average length of the longest three new roots

INT: Ice nucleation temperature.

$\mathrm{LT}_{(10,50,90)}$ : freezing damage indexes of leaves

NNR: new roots longer that $1 \mathrm{~cm}$

$\mathrm{RWC}_{\mathrm{tlp}}$ : relative water content
Morpho-physiological attributes exhibited in response to drought hardening at the end of the growing season of Eucalyptus globulus Labill under nursery conditions were studied to evaluate the effect of three drought hardening treatments in morpho-physiological traits used as suitable indicators of drought hardiness, such as, plant growth, root growth potential, plant water relationships and survival. Freezing resistance of drought hardened plants was also studied in order to evaluate cross hardening effects in cuttings of Eucalyptus globulus Labill. Drought hardening consisted in induced water stress by watering restriction, until plant stem xylem water potentials $\left(\Psi_{\text {pd }}\right)$ reached to-0.2, -1.3 and -2.4 MPa. Two water stressrewatering cycles were applied during 54 days of treatment. The hardening treatments caused a significant reduction in plant height, leaf area, specific leaf area, plant, leaf, stem and root biomass. However, stem diameter was not affected. Root growth potential increased with the exposure to moderate water stress (-1.3 MPa). Drought hardening treatments have not effect on water relationship parameters such as saturation osmotic potential $\left(\boldsymbol{\Psi} \boldsymbol{\pi}_{\text {sat }}\right)$, volumetric module of elasticity (e), relative water content $\left(\mathrm{RWC}_{\mathrm{tlp}}\right)$ and osmotic potential $\left(\Psi \pi_{\mathrm{tlp}}\right)$ at the turgor loss point. Only $1.7 \%$ and $6 \%$ of dehydrated dead plants were observed on treatments at $\mathbf{- 1 . 3}$ and $\mathbf{- 2 . 4}$ MPa respectively. Finally, the freezing damage index of leaves $\left(\mathrm{LT}_{50}\right)$ was not significantly affected by drought hardening treatments. Furthermore, a reduction of $1.1^{\circ} \mathrm{C}$ of supercooling capacity was observed at $-2.4 \mathrm{MPa}$. As a conclusion, drought hardening is an important step of plants production programs during the final phase of nursery, because changes in morphological attributes caused by exposure to moderate drought, enable the plants to maintain the balance between transpiration and absorption areas and increase the capacity of plants to generate new roots.

The high pulp yield and fast growth of Eucalyptus globulus Labill have determined that about 436.706 ha have been planted in Chile representing approximately $21.3 \%$ of the national planted territory (Avila et al. 2005). Due to the high rates of forestry plantation establishment during the past 15 years, availability of edaphoclimatically favourable land is scarce, therefore, it has been necessary the use of less favourable sites for plantation establishment like costal dry lands and above 650 m.a.s.l. in the foot hills of Andes Mountains. Both sites exhibited severe dryness during summer and low temperature in winter. The evident challenges to improve the Eucalyptus globulus capacity to withstand drought and freezing temperatures, and its clonal propagation have received major attention (Pita and Pardos, 2001; Ngugi et al. 2003). However, there is no substantial information about morpho-physiological variations induced by an acclimation phase under nursery (phenotypic plasticity), which is essential for water stress survival of plants in unfavourable sites (Guarnaschelli et al. 2006).

It is known that sub lethal water stress exposed plants exhibited less drought injury than no stressed plants (VillarSalvador et al. 2004; Banon et al. 2006). Several studies have been conducted about drought and its associated effects on Eucalyptus globulus under several controlled and natural environments (White et al. 2000; Pita and Pardos, 2001; Gindaba et al. 2004). During the acclimation to water stress, reduction in growth rates and changes in the balance between aerial and root growth are usually seen (Hsiao and $\mathrm{Xu}, 2000)$. Plant morphological attributes like collar diameter, plant height have been consistently reported as good indicators for survival and growth potential after planting (Mason, 2001). Root growth potential is also a useful indicator of plant vitality, especially when plants are planted in stressful sites (Ritchie and Tanaka, 1990). Plants can respond to drought with a variety of mechanisms that allows them to avoid water stress or tolerate certain levels of desiccation (Larcher, 2003). Osmotic adjustment and the increment of cell wall elasticity have been shown that help to maintain cellular turgor at low tissue water potentials in Eucalyptus sp. (Guarnaschelli et al. 2003), which could be essential for plant survival and growth during drought. Plant water relations give useful information about the capacity of trees to maintain growth, gas exchange and water use during summer drought (White et al. 2000).

*Corresponding author 
Finally, there is evidence that cold acclimation and water stress induce cell dehydration which triggers a series of common physiological responses like decrease of protoplast osmotic potential and common proteins synthesis (Pérez et al. 1997; Chaves et al. 2003), therefore, a drought acclimated plant should be more freezing resistant than a non-acclimated one.

It is unknown how desiccation resistance and cold acclimation are modulated by the nursery environment and in some cases published information is contradictory (Colombo et al. 2003). There is limited information about how morphological traits usually used to asses growth potential are suitable indicators of drought hardiness and if water stress induce freezing hardiness in nursery plants of Eucalyptus globulus. Therefore, the objective of this study was to evaluate the effect of drought hardening in plant growth, root growth potential, plant water relations and freezing resistance of rooted cuttings of Eucalyptus globulus Labill at the nursery phase.

\section{MATERIALS AND METHODS}

\section{Plant material and experimental setup}

A total of 2,800 eight month old rooted cuttings of Eucalyptus globulus Labill were obtained from the Forestry Company Bosques Arauco S.A. Chile. Cuttings were rooted in trays of 88 containers of $130 \mathrm{ml}$ each, using a mixture of turf: perlite $1: 1(\mathrm{v} / \mathrm{v})$ with a total porosity, aeration and water storage capacity of 75,32 and $42 \%$ respectively. Growth density was 393 plants $\mathrm{m}^{-2}$, in a greenhouse with mist irrigation. After rooting, plants were growth outdoor for 5 months and then for drought hardening were kept under transparent roof in order to cover from rainfall. Local environmental conditions were monitored by a weather station installed in the place of experiment (Table 1).

\section{Drought hardiness}

Three different treatments were applied and consisted in watering restriction until plants reach a total predawn stem xylem water potential of ( $\Psi_{\mathrm{pd}} ;-0.2,-1.3$ and $\left.-2.4 \mathrm{MPa}\right)$ and then were watered to reach substrate saturation and a new cycle of drought proceed. The treatment with $\Psi_{\mathrm{pd}}=-0.2$ $\mathrm{MPa}$ was considered non-stressed control, the $-1.3 \mathrm{MPa}$ (moderate stress) value is in the center of the target range (1.0 to $-1.5 \mathrm{MPa}$ ) for drought hardening processes that has been commonly used in most USA forest nurseries (Landis, 1989) and is just below to the wilting point of the experiment's plants. Finally $-2.4 \mathrm{MPa}$ (severe stress) correspond to a permanent wilting point of experiment's plants. The hardening phase last 54 days (May-June 2004) and include two cycles of low water potential (Figure 1). Total stem xylem water potential were measured in a sample of 20 plants per treatment $(n=20)$ at predawn with the Scholander pressure chamber (Soilmoisture Equipment Corp, Santa Barbara, CA USA), approximately every two

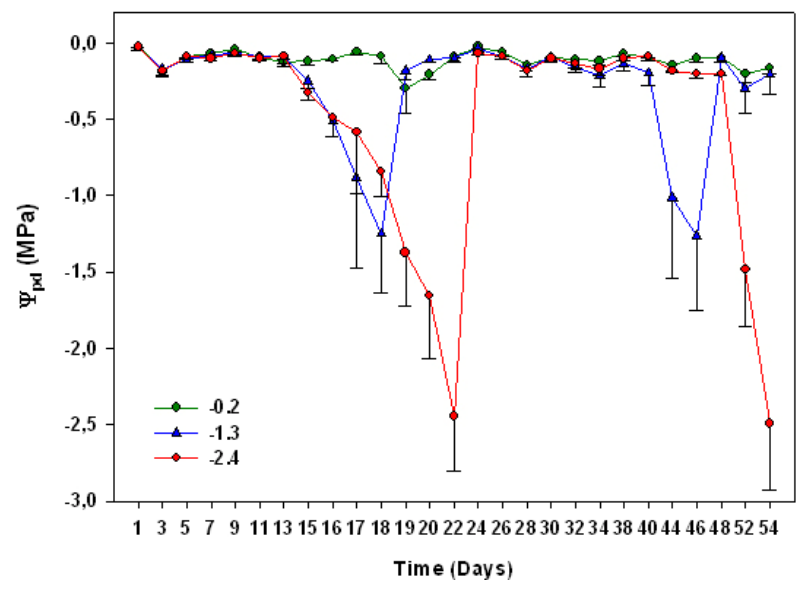

Figure 1. Variation of total stem xylem water potential $\left(\Psi_{\mathrm{pd}}\right)$ of Eucalyptus globulus during drought hardening time course. Three drought hardening treatments $(-0.2,-1.3$ and $-2.4 \mathrm{MPa}$ ) were applied during 54 days. Error bars represent $-1 \mathrm{SE}, \mathrm{n}=20$.

days. The treatment with $\Psi_{\mathrm{pd}}=-0.2 \mathrm{MPa}$ was considered non-stressed control maintaining a watering frequency of about 7 days. The $\Psi_{\text {pd }}$ did not change until day 13, then decreased at a rate of $-0.27 \mathrm{MPa}$ day $^{-1}$ reaching the objective water potentials at 18 and 22 days respectively, in the first cycle and after rewatering plant reached again the objective water potential after 46 and 54 days respectively (Figure 1). Before the beginning of the assay and immediately after the hardening treatment, all plants were profusely watered in order to uniform the water content of the substrate to an initial saturated condition.

\section{Growth}

Twenty plants from each treatment were taken approximately every 5 days to determine plant height $(\mathrm{cm})$, stem diameter $(\mathrm{mm})$, root, stem, leaf and total dry biomasses (g). Additionally, leaf area and specific leaf area were determined using a leaf area meter Li-3100 (Li-Cor Inc., Lincon, Ne USA).

\section{Root growth potential}

Twenty plants from each treatment were taken every 13 days of treatment, the substrate was carefully removed and roots extensively washed. New roots (white roots) were removed and then plants were placed in an aeroponical chamber (Forcap Ltda., Concepción, Chile). The chamber was programmed to provide a pulse of $6 \mathrm{sec}$ of water mist at $22^{\circ} \mathrm{C}$ directly to the root system every $10 \mathrm{~min}$. Photoperiod was $16 \mathrm{hrs} \mathrm{light} \mathrm{at} \mathrm{a} \mathrm{PFD} \mathrm{of} 50 \mu \mathrm{molm}^{-2} \mathrm{~s}^{-1}$ air temperatures for the aerial part of the plant oscillate from $16-20^{\circ} \mathrm{C}$ day and $8-12^{\circ} \mathrm{C}$ night. After 28 days, the number of new roots longer that $1 \mathrm{~cm}$ (NNR) and the average length of the longest three new roots (ARL) were recorded. 


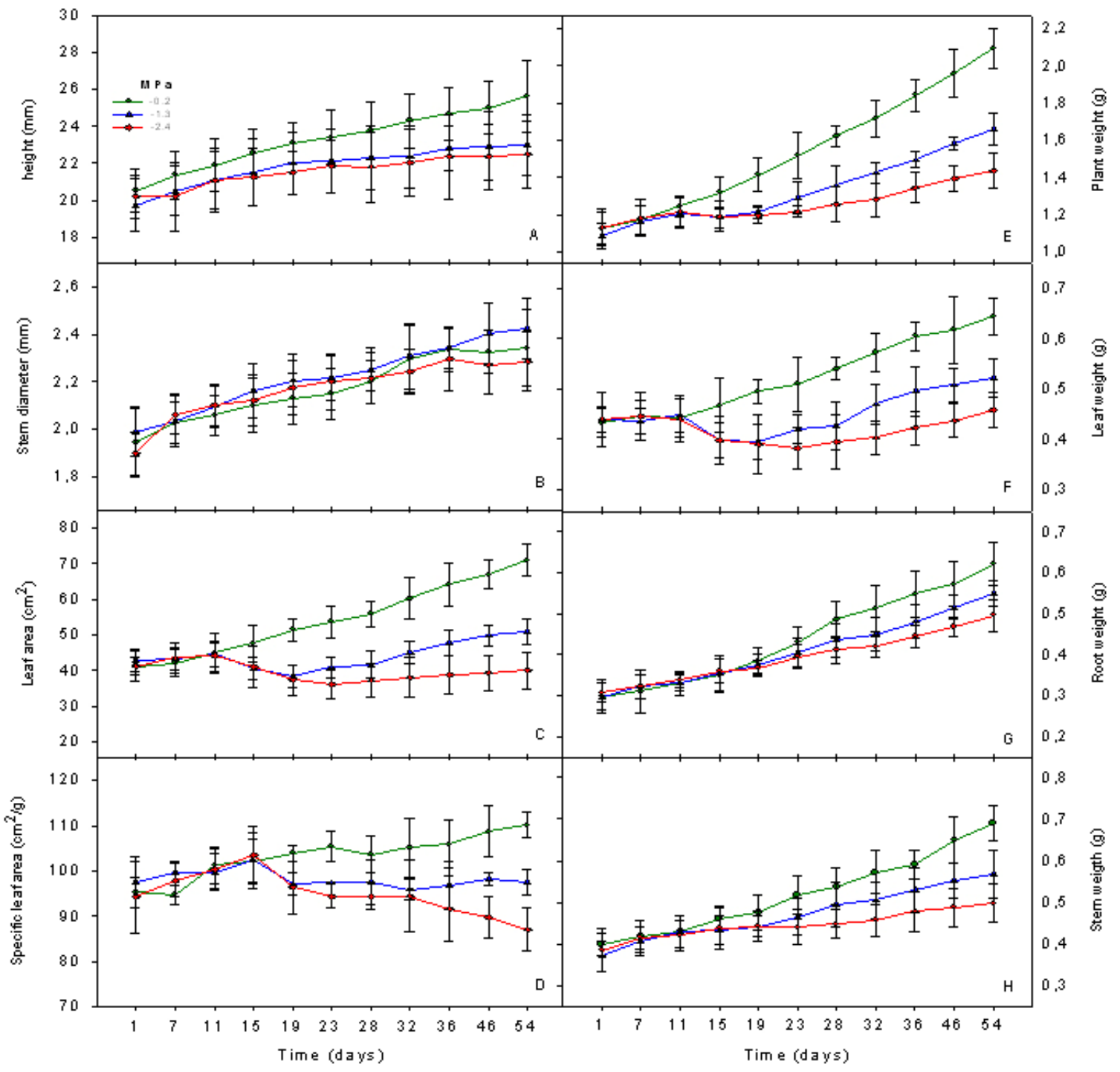

Figure 2. Variation in morphological traits during the time course of drought hardening. The evolution of height (A), stem diameter $(B)$, leaf area $(C)$ specific leaf area $(D)$, plant $(E)$, leaf $(F)$, root $(G)$ and stem biomass $(H)$ of $E$. globulus plants in response to three drought hardening treatment $(-0.2,-1.3$ and $-2.4 \mathrm{MPa})$ were evaluated. Error bars represent $\pm 1 \mathrm{SE}, \mathrm{n}=20$.

\section{Plant water relations}

Pressure-volume curves were developed combining air dehydration of the sample with measurements of xylem stem water potential (Tyree and Hammel, 1972). The procedure consisted in the application of pressure with a Scholander pressure chamber (Soilmoisture Equipment Corp, Santa Barbara, CA USA) to the terminal end of the plant cut at $10 \mathrm{~cm}$ from the apex, until the internal tension of the xylem equilibrate with the pressure of the chamber and a humid film was seen at the cut surface $\left(\Psi_{\text {sxtw }}=\right.$ Stem xylem total water potential). Immediately after, the apex was weighed $\left(\mathrm{W}_{\mathrm{f}}\right)$. Three plants were used at each step $(\mathrm{n}=$ 3 ), and then they were left to dry on top of a bench and the procedure was repeated again during $8 \mathrm{hrs}$. After the last measurement plant tissue was completely dry at $85^{\circ} \mathrm{C}$ for 48 hrs and dry weight was determined $\left(\mathrm{W}_{\mathrm{d}}\right)$ Weight at maximum turgor $\left(\mathrm{W}_{\mathrm{t}}\right)$ was obtained by extrapolation to $\Psi_{\text {sxtw }}=0$ in the curve $\Psi_{\text {sxtw }}$ vs fresh weight $\left(\mathrm{W}_{\mathrm{f}}\right)$. Relative water content (RWC) was calculated as $\left(\mathrm{W}_{\mathrm{f}}-\mathrm{W}_{\mathrm{d}}\right) /\left(\mathrm{W}_{\mathrm{t}}\right.$ $\mathrm{W}_{\mathrm{d}}$ ). Parameters like, osmotic potential at saturation point $\left(\Psi \pi_{\text {sat }}\right), \mathrm{RWC}$ at turgor loss $\left(\mathrm{RWC}_{\mathrm{tpp}}\right)$ and osmotic potential at turgor loss $\left(\Psi \pi_{\mathrm{tlp}}\right)$ were obtained from the pressurevolume curve (P-V) (Tyree and Hammel, 1972). The pressure potential $\left(\Psi_{\mathrm{p}}\right)$ was calculated from the difference between $\Psi_{\text {sxtw }}$ and the osmotic water potential derived from $\mathrm{P}-\mathrm{V}$ curve. The tissue volumetric module of elasticity (e) was calculated as:

$$
\varepsilon=\frac{\Delta \Psi_{p}}{\Delta R W C} R W C
$$


Where $\Delta \Psi_{\mathrm{p}} / \Delta R W C$ is the slope of a curve obtained when $\Psi_{\mathrm{p}}$ is expressed as a function of RWC within the range of positive turgor (White et al. 2000; Ngugi et al. 2003). Osmotic adjustment was defined as the difference between $\Psi \pi_{\text {sat }}$ from the drought hardiness treatments $(-1.3,-2.4$ $\mathrm{MPa})$ and $\Psi \mathrm{p}_{\text {sat }}$ from the control treatment $(-0.2 \mathrm{MPa})$ (Ngugi et al. 2003; Villar-Salvador et al. 2004).

\section{Freezing resistance}

Three weeks after the hardening phase, 12 plants from each hardening treatment were collected and 2 leaf disks $(8 \mathrm{~mm}$ diameter) were obtained from each third pair of leaves which are the first totally expanded. The leaf disks were put into a polycarbonate test tubes and exposed to freezing temperaturas $-3.0,-4.5,-6.0,-7.5$ and $-9.0^{\circ} \mathrm{C}$, without ice nucleating agents in a chamber cooled by forced cooling air. The above zero rate of cooling was $30^{\circ} \mathrm{C} \mathrm{h}^{-1}$ and below zero $2.1^{\circ} \mathrm{C} \mathrm{h}^{-1}$. Time of exposure to each objective temperature was $1.5 \mathrm{hrs}$ and then plant were thawed at $4^{\circ} \mathrm{C}$ in darkness for $24 \mathrm{hrs}$ and the leaf injury indexes $\left(\mathrm{LT}_{10}\right.$, $\mathrm{LT}_{50}, \mathrm{LT}_{90}$ ) were evaluated in leaf disks by ion leakage measuring relative electrolyte conductivity (RC) according to Moraga et al. (2006). Thermal analyses were conducted in the same leaf material in order to determine ice nucleation temperature and freezing point of the leaf (Larcher, 2003). Essentially the procedure was the same as used by Reyes-Díaz et al. (2005), briefly, a piece of leaf was attached to a fine type $\mathrm{T}$ thermocouple copperconstantan, gauge 30, junction diameter about $0.5 \mathrm{~mm}$ (Cole Palmer, Vernon Hills, IL USA), immediately enclosed in a cryotube to avoid tissue dehydration. Cryotubes were immerse in a cryostat (C25P, ThermoHaake, Karlsruhe, Germany) and a linear descend was programmed from 0 to $-15^{\circ} \mathrm{C}$ at a rate of $2^{\circ} \mathrm{C} \mathrm{h}^{-1}$. The temperature was continuously monitored and registered every $1 \mathrm{sec}$ with a USB data adquisition system (Personal Daq/56, IOtech. Inc, Cleveland, Ohio USA) connected to a personal computer.

\section{Data analyses}

Data were analyzed by one-way repeated-measures ANOVA, considering the effect of drought hardening treatment $(-0.2,-1.3$ and $-2.4 \mathrm{MPa})$ as a factor measured at several times of exposition (Piepho et al. 2003). All variables were subjected to normality and variance homogeneity test prior to ANOVA. A post-hoc Tukey test was applied when ANOVAS give significant differences, considering $\mathrm{P} \leq 0.05$. All these analyses were performed using the PROC Mixed procedure of SAS software version 9.1, 2001 (SAS Institute Inc. Cary, NC, USA).

\section{RESULTS}

\section{Growth}

The interaction between drought hardening treatment and its duration was not statistically significant for variables plant height and stem diameter. Nonetheless, plants from the control treatment $(-0.2 \mathrm{MPa})$ exhibited higher plant height than -1.3 and $-2.4 \mathrm{MPa}$ treatments, which did not differ from each other. Plant height showed a significant increase at day 19 of treatment respect to the beginning of the experiment. However plant height did not differ from day 15 to the end of treatments (day 54) (Figure 2a) Stem diameter was not affected by drought hardiness treatments but showed a significant increase with time exposure from day 15 (Figure 2b). Interaction between hardening treatment and its duration significantly affected leaf area and specific leaf area (Figure $2 \mathrm{c}$ and Figure $2 \mathrm{~d}$ ). Leaf area of plant exposed to $-0.2 \mathrm{MPa}$ increased at a constant rate exhibiting a significant higher leaf area than the other treatments from day 19, while other treatments showed a decrease in leaf area without differing from each other until day 19. Plant from treatment $-1.3 \mathrm{MPa}$ exhibited an increase in leaf area toward the end of the experiment, which was not observed in plant from treatment -2.4 MPa. Nevertheless, both treatments no reached a significant difference during the hardening phase (Figure 2c). The SLA increased without significant difference within treatments until day 15. SLA was significantly higher in plants exposed to $-0.2 \mathrm{MPa}$ from day 36 , however SLA decrease in the other treatments toward day 19, and plants of treatment $-1.3 \mathrm{MPa}$ maintains the same value of SLA until the end of the experiment, while plants from treatment $-2.4 \mathrm{MPa}$ significantly decreased their SLA (Figure 2d).

Weight of plants exposed to $-0.2 \mathrm{MPa}$ increased significantly from 28 to 54 days, respect to the beginning of the experiment. Plant weight did not differ within drought hardiness treatments until day 36 . Plants exposed to -1.3 and $-2.4 \mathrm{MPa}$ did not increase their weight until day 28 , from this time ahead weights of plants from treatment -1.3 $\mathrm{MPa}$ increased at a higher rate than those from treatment at $-2.4 \mathrm{MPa}$, nevertheless, not significantly different were

Table 1. Average climatic variables during drought hardening treatments. Substrate (STmax, STmin) and air (ATmax, ATmin,) maximum and minimum temperatures, maximum solar radiation (SR), maximum and minimum relative humidity (RHmax, RHmin) and wind velocity (WV) were registered. Values are the average of 54 daily measurements $\pm 1 \mathrm{SE}$.

\begin{tabular}{|c|c|c|c|c|c|c|c|}
\hline $\begin{array}{c}\text { STmax } \\
\left({ }^{\circ} \mathbf{C}\right)\end{array}$ & $\begin{array}{c}\text { STmin } \\
\left({ }^{\circ} \mathbf{C}\right)\end{array}$ & $\begin{array}{c}\text { ATmax } \\
\left({ }^{\circ} \mathbf{C}\right)\end{array}$ & $\begin{array}{c}\text { ATmin } \\
\left({ }^{\circ} \mathbf{C}\right)\end{array}$ & $\begin{array}{c}\text { SRmax } \\
\left(\mathbf{w ~ m ~ m}^{-2}\right)\end{array}$ & $\begin{array}{c}\text { RHmax } \\
(\mathbf{\%})\end{array}$ & $\begin{array}{c}\text { RHmin } \\
(\%)\end{array}$ & $\begin{array}{c}\mathbf{W V} \\
\left(\mathbf{m ~ s}^{-1}\right)\end{array}$ \\
\hline $15.7 \pm 0.3$ & $6.8 \pm 0.4$ & $16.8 \pm 0.4$ & $6.3 \pm 0.4$ & $339 \pm 22$ & $94.9 \pm 0.2$ & $65 \pm 2.1$ & $0.4 \pm 0.4$ \\
\hline
\end{tabular}


detected until the end of treatments (Figure 2e). Leaf weight of plants exposed to $-0.2 \mathrm{MPa}$ increased reaching significantly higher values than leaves of -1.3 and $2.4 \mathrm{MPa}$ from day 23. Plants exposed to -1.3 and $-2.4 \mathrm{MPa}$ showed no significant differences in leaf weight between each other during the experiment (Figure 2f). Root weight increased significantly since day 23 , drought hardening treatment did not affect root weight until day 36, from this day ahead differences in root weight were observed only between treatments at -0.2 and $-2.4 \mathrm{MPa}$ (Figure $2 \mathrm{~g}$ ). Stem weight of plants exposed to -0.2 and $-1.3 \mathrm{MPa}$ increase from day 28 having significant differences only at day 54 . Plants treated at -2.4 MPa did not increase their stem weight, showing no significant differences from treatment at $-1.3 \mathrm{MPa}$ during the experiment (Figure $2 \mathrm{~h}$ ). The shoot/root biomass ratio was significantly reduced by the drought hardening regime $(-1.3$ and $-2.4 \mathrm{MPa})$ from day 15 to 23 and in the final 8 days of hardening. However the control plants $(-0.2 \mathrm{MPa})$ also reduced its shoot/root biomass ratio since day 19 to 28 (Figure 3).

\section{Root growth potential}

There was a highly significant interaction between intensity and duration of drought hardening for number of new roots, longer than $1 \mathrm{~cm}(\mathrm{NNR})$ and for the average length of longest three roots (ARL). The NNR of the extreme treatments $(-0.2$ and $-2.4 \mathrm{MPa})$ significantly increased until day 12 , while the NNR in the moderate drought hardening treatment $(-1.3 \mathrm{MPa})$ raised until day 28. All treatments then decreased reaching similar values to the beginning of the experiment. There was no significant difference in the NNR within drought hardening treatments except in the day 28 , where plants exposed to $-1.3 \mathrm{MPa}$ reached the highest value (Figure $4 \mathrm{a}$ ). The ARL tended to increase until days 12 or 28 depending on the treatment, and then decrease significantly in all treated plants during the time course. There were significant differences within treatments only at day 28 (Figure 4b).

\section{Water relations}

Twenty days after drought hardening, plants did not exhibited significant differences in the $\mathrm{P}-\mathrm{V}$ derived

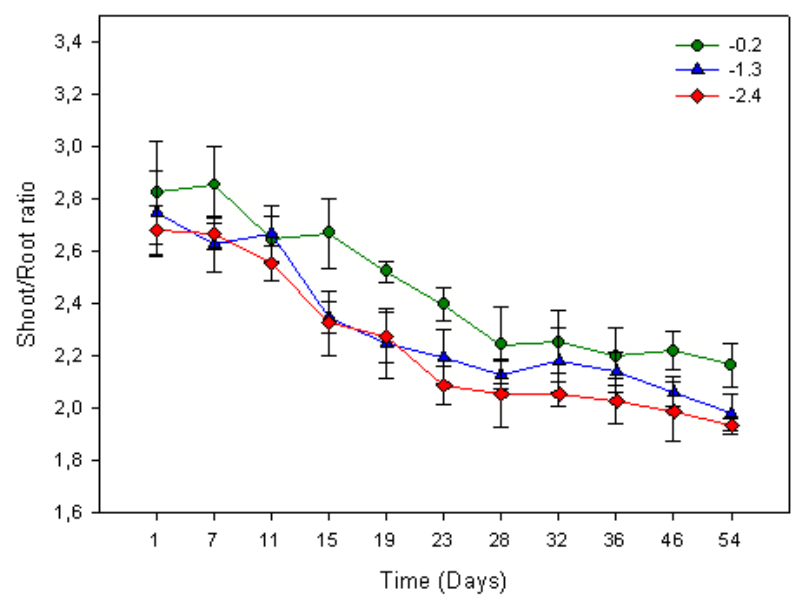

Figure 3. Shoot/Root biomass ratio of $E$. globulus in response to drought hardening treatment. Variation of shoot/root biomass was evaluated during the time course of three different drought treatments $(-0.2,-1.3$ and $-2.4 \mathrm{MPa})$. Error bars represent SE, $(n=20)$.

parameters $\Psi \pi_{\text {sat }}, \mathrm{CRA}_{\text {tlp }}, \Psi \pi_{\text {tlp }}$ and e (Table 2). Indicating that even the most severe treatment, $-2.4 \mathrm{MPa}$, allows the plant to restore their water balance.

\section{Cold injury}

Drought hardening treatment did not affect freezing resistance of E. globulus plants measured three weeks after treatments. All treatments exhibited similar freezing injury, from incipient $\left(\mathrm{LT}_{10}\right)$ to severe $\left(\mathrm{LT}_{90}\right)$ damage (Figure 5). Ice nucleation temperature (INT) was significantly increased in most severe treatment reaching $-5.5^{\circ} \mathrm{C}$, while the other two treatments exhibited INT around $-6.5^{\circ} \mathrm{C}$ which indicates that supercooling capability was decreased after severe drought treatment.

\section{DISCUSSION}

\section{Growth and morphology}

Drought acclimation treatments significantly reduced

Table 2. Plant water relations obtained from P-V curves. Osmotic potential at saturation $\left(\Psi_{\pi_{\text {sat }}}\right)$, relative water content at turgor loss point $\left(\mathrm{RWC}_{\mathrm{tp}}\right)$, Osmotic potential at turgor loss point $\left(\Psi_{\mathrm{T}_{\mathrm{tp}}}\right)$ and modulus of elasticity (e) of Eucalyptus globulus, after drought hardening regimes $(-0.2,-1.3$ and $-2.4 \mathrm{MPa})$. Values are means $\pm 1 \mathrm{SE},(n=3)$. Means with different letters are significantly different $(P \leq 0.05)$.

\begin{tabular}{|c|c|c|c|c|}
\hline $\begin{array}{c}\text { Hardening regime } \\
\text { (MPa) }\end{array}$ & $\boldsymbol{\Psi}_{\boldsymbol{\pi}_{\text {sat }}}(\mathbf{M P a})$ & $\mathbf{R W C}_{\text {tlp }}(\%)$ & $\boldsymbol{\Psi}_{\boldsymbol{\pi}_{\text {tlp }}}(\mathbf{M P a})$ & $\mathbf{e}(\mathbf{M P a})$ \\
\hline-0.2 & $-1.631 \pm 0.020 \mathrm{a}$ & $0.780 \pm 0.010 \mathrm{a}$ & $-2.228 \pm 0.039 \mathrm{a}$ & $11.49 \pm 0.75 \mathrm{a}$ \\
\hline-1.3 & $-1.719 \pm 0.130 \mathrm{a}$ & $0.776 \pm 0.018 \mathrm{a}$ & $-2.375 \pm 0.022 \mathrm{a}$ & $12.76 \pm 2.28 \mathrm{a}$ \\
\hline-2.4 & $-1.820 \pm 0.110 \mathrm{a}$ & $0.807 \pm 0.020 \mathrm{a}$ & $-2.375 \pm 0.119 \mathrm{a}$ & $13.05 \pm 0.57 \mathrm{a}$ \\
\hline
\end{tabular}




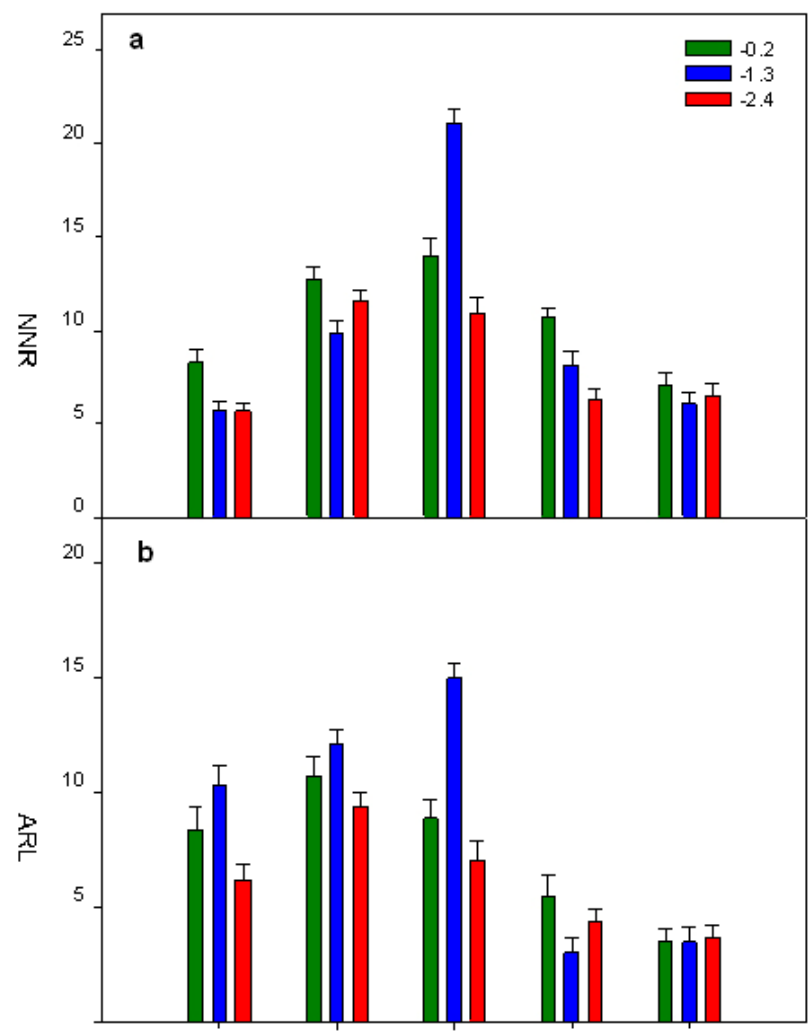

Figure 4. Root growth potential of E. globulus in response to drought hardening treatment. Variation of (a) Number of new roots longer than $1 \mathrm{~cm}(\mathrm{NNR})$ and (b) the average length of longest three roots (ARL) were evaluated during the time course of three different drought treatments $(-0.2,-1.3$ and $-2.4 \mathrm{MPa})$. Error bars represent SE, $(n=20)$. Different letters between times indicate significant differences within each drought hardening treatment and asterix show significant differences between treatments at each measuring time (Tukey test, $p \leq 0.005$ ).

growth rates, however some variables like stem diameter, root weight and stem weight were less sensitive to water stress (Figure 2 and Figure 3). Acclimation to substrate low water availability resulted in morpho-physiological adjustments that improve plant water balance (Chaves et al. 2003; Shvaleva et al. 2005). Both, time of exposure and intensity of water stress significantly reduced shoot/root biomass ratio (Figure 3). The effect of time of exposure on the decrease of shoot/root ratio could be due to a decrease in temperature and photoperiod shortage toward autumn. Leaf area was not affected by any drought hardening treatment until day 11 , when plants from treatments at -1.3 and-2.4 MPa decreased leaf area mainly due to a defoliation that reach about 26 and $33 \%$ respect to the control at -0.2 $\mathrm{MPa}$ at days 19 and 23 of treatment respectively. A particularly efficient mechanism to reduce transpiratory surface is the partial leaf abscission (Larcher, 2003). The abscission of an important part of old and basal leaves observed during our experiments is a well known strategy to affront drought of E. globulus (Osorio et al. 1998). Plants under drought hardening reactivate leaf expansion but at lower rates than control plants, exhibiting significant leaf area reduction, $30 \%$ at $-1.3 \mathrm{MPa}$ and $44 \%$ at $-2.4 \mathrm{MPa}$, at the end of the experiment (Figure 2c). Drought hardened plants significantly reduced leaf area, being this variable one of the most sensitive to water stress as reported by several studies in E. globulus (Pita and Pardos, 2001; Costa E Silva et al. 2004).

There is evidence that root growth is less affected by drought than stem or shoots (Hsiao and $\mathrm{Xu}, 2000$ ). Consistently, plants of E. globulus exhibited only an 11 and $19 \%$ reduction of root biomass in plants treated at -1.3 and $2.4 \mathrm{MPa}$ respectively, while reductions in total plant biomass reached 23 and $34 \%$ in corresponding treatments, being leaf biomass the main determinant of this biomass reduction. Similar reductions in E. globulus leaf area and plant biomass were found by Pita and Pardos (2001).

Drought hardening treatments of $-1.3 \mathrm{MPa}$ and $-2.4 \mathrm{MPa}$ significantly reduced SLA, 8 and $14 \%$ respectively. Similar results have been reported by Pita and Pardos, (2001); Costa E Silva et al. (2004) and Marron et al. (2003). The maintenance of the balance between transpiration and absorption areas when water availability is reduced seems to be a determinant key of E. globulus plant performance (Marron et al. 2003; Costa E Silva et al. 2004).

Drought hardening treatments, $-1.3 \mathrm{MPa}$ and $-2.4 \mathrm{MPa}$ applied under nursery, significantly reduced plant height, leaf area and specific leaf area, stem and leaf biomass. Plant height, which is considered as a predictor of growth potential in the field, was reduced $3 \%$ and $7 \%$ in treatments $-1.3 \mathrm{MPa}$ and $-2.4 \mathrm{MPa}$ respectively. Nevertheless, excessive plant height is a disadvantage in water stressed sites (South and Zwolinski, 1997). A good quality plant is the biggest possible which maintains acceptable levels of survival in a designated site. Stem diameter, is considered the best predictor of survival and initial growth in a plantation (South and Zwolinski, 1997) which did not differ within our drought hardening treatments. Mortality of plants by dehydration was low but significantly different within treatments $(P \leq 0.01)$. Plants exposed to -1.3 and $-2.4 \mathrm{MPa}$ only exhibited 1.7 and $6 \%$ mortality respectively.

\section{Root growth potential}

Root growth potential has become one of the most commonly used measures to report forest nurseries quality (Simpson and Ritchie, 1997). Formation of new roots is critical for establishment after transplanting (Kaushal and Aussenac, 1989), especially in sites with water limitations. Both, the number of new roots and the average length of the three longest roots from treatment $-1.3 \mathrm{MPa}$ increased significantly from the beginning until day 28 having values 41 and $47 \%$ higher than treatments at -0.2 and $-2.4 \mathrm{MPa}$ respectively (Figure 4). These results indicates that exposure to a single cycle of moderate $(-1.3 \mathrm{MPa})$ water stress stimulate formation of new roots. These results are inconsistent with those reported by Tinus (1996) for 
Pseudotsuga menziesii, who found that NNR decreased with the exposure to a previous event of water stress. However, moderate water stress during drought hardening phase at nursery increase drought resistance, but plants need some time to develop it (Guarnaschelli et al. 2003). Costa E Silva et al. (2004) reported higher root length in water stressed clones of E. globulus compares to well irrigated plants. The reductions of NNR and ARL in the severe treatment, $-2.4 \mathrm{MPa}$, indicate a pour plant functional integrity according to Simpson and Ritchie (1997).

\section{Plant water relations}

Drought hardening treatments did not affect P-V derived parameters $\Psi \pi_{\text {sat }}, \mathrm{CRA}_{\text {tlp }}, \Psi \pi_{\text {tlp }}$ and e, evaluated 20 days after drought hardening, which agreed with data reported by Villar-Salvador et al. (2004) in plants of Quercus ilex. These results demonstrate that physiological modifications induced by water stress are transient, what agreed with White et al. (2000) who states that compatible solutes accumulated in plants of E. leucoxylon and E. platypus exposed to drought in the field are lost or converted to osmotically inactive compounds during a rehydration period of only 12 to $14 \mathrm{hrs}$. On the other hand, it could be that this particular genotype of E. globulus did not modify its stem water relations, as it has been reported to some genotypes of E. globulus subjected to water stress, indicating intraspecific differences in tissue water relations (Pita and Pardos, 2001). A decrease in osmotic water potential results in higher pressure potentials at a particular water potential of leaves, while and increased in cell wall elasticity results in lower changes in pressure potential for a given change in RWC (Lemcoff et al. 2002). Although no significant differences were observed in the magnitude of osmotic adjustment in our drought hardening treatments -1.3 MPa and -2.4 MPa which exhibit -0.09 and -0.19 MPa respectively. These values are in the range reported for $E$. globulus growing in sites under water stress (Correia et al. 1989; Ngugi et al. 2003). The stem e changed from 11.5 to 13.1 MPa, given the limited adjustment of cell wall elasticity related to the level of osmotic adjustment observed in this E. globulus genotype. It seems that the last mechanism is an important determinant of drought tolerance in this genotype.

\section{Freezing resistance}

Thermal analyses combined with a freezing injury index (LTs) allow us to predict that the studied genotype is not able to tolerate ice formation within its leaf tissues, registering incipient damage at higher temperatures than INT. This behavior allows us to classify this E. globulus genotype as freezing sensitive. On the other hand, drought hardening did not significantly modify damage indexes of leaves, which is likely due to the long time after treatment (three weeks) that freezing resistance was evaluated. Hence, no significant relationship was found between the measured water-status and freezing tolerance parameters. This result is consistent with those found in plant water relations where no major differences between plants exposed to drought hardening were found after 20 days of normal irrigation. It is known that after short time of normal irrigation most of compatible solutes that also may cryoprotect leaf cells are completely lost after few hours of rehydration (White et al. 2000). The higher INT exhibited after two weeks of normal irrigation in plants previously subjected to the most severe drought hardening treatment (-2.4 MPa) even higher than incipient damage $\left(\mathrm{LT}_{10}\right)$ allows us to state that plants slightly decrease their limited supercooling capacity after this treatment and were able to withstand ice formation within their tissues without suffering damage in a small range of freezing temperatures. The observed increased INT in plants that reached the lowest water potential (-2.4 MPa) during drought hardening may be related to the slightly higher cell wall elasticity exhibited by this plants (Table 2). It is recognized that cold acclimation increase cell wall rigidity decreasing extracellular ice nucleation and increasing cold tolerance (Fujikawa and Kuroda, 2000). Alternatively, it may be speculated that the extensive hydration state reached after rehydration due to the higher water potential gradient between substrate and plant tissues generated immediately after watering may influence ice nucleation temperatures, because higher hydration state increase the probability of ice formation at low temperatures (Pearce, 2001). It is important to notice that minimum average air temperature at the experimental site was $6.3^{\circ} \mathrm{C}$ which is out of the temperature range that E. globulus may express its maximum potential freezing resistance (Almeida et al. 1994).

In consequence, moderate drought hardening under the final phase of nursery is an important part of plant management programs for plant production to establish plantations in the coastal dry lands and above 650 m.a.s.l. in the Andes Mountains in Chile since drought hardened

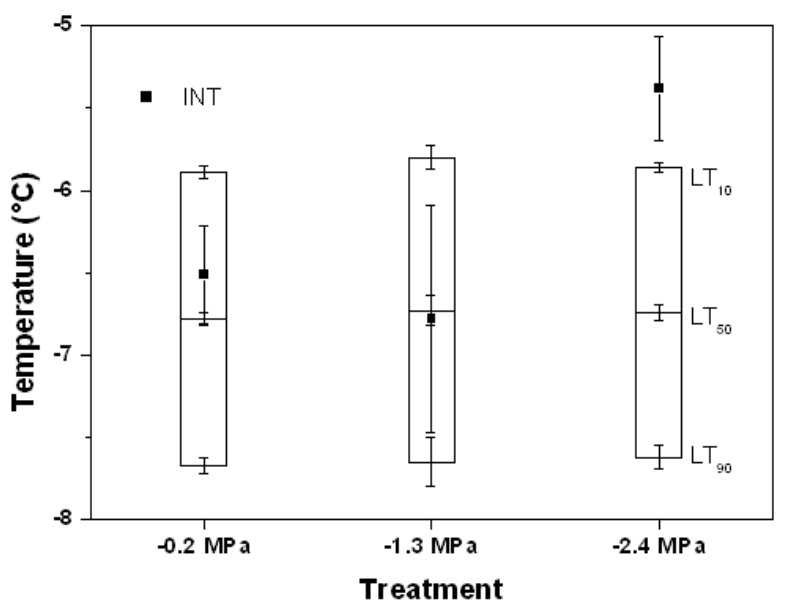

Figure 5. Freezing resistance in drought hardened plants. After drought treatments $(-0.2,-1.3$ and $-2.4 \mathrm{MPa})$, lethal temperatures for 10,50 and $90 \%$ of leaf damage $(n=8)$ and ice nucleation $(n=6)$ temperatures were determined. Vertical error bars represent standard error. 
plants are best prepared to affront severe dryness during the first days of plantation and subsequently will restart growing after drought.

\section{ACKNOWLEDGMENTS}

The authors thank financial support and infrastructure for plant growth received from the company Forestal Arauco S.A. Also thank the equipments provided by INNOVA BIO-BIO 03-B1-210-L1 and Ecophysiology equipment provided by MECESUP, UCO 0214.

\section{REFERENCES}

ALMEIDA, M.H.; CHAVES, M.M. and SILVA, J.C. Cold acclimation in eucalypt hybrids. Tree Physiology, 1994, vol. 14, p. 921-932.

AVILA, A.; MUÑOZ, J.C.; PEÑA, O.; URIBE, M. AND CÉSPEDES, E. Acualización de superficie de plantaciones forestales IV a XI regiones a diciembre de 2005, INFOR, 2005 [cited November 2005]. Available from Internet: http://www.infor.cl.

BAÑON, S.; OCHOA, J.; FRANCO, J.A.; ALARCÓN, J.J. and SÁNCHEZ-BLANCO, M.J. Hardening of oleander seedlings by deficit irrigation and low air humidity. Environmental and Experimental Botany, May 2006, vol. 56 , no. 1, p. 36-43.

COLOMBO, Stephen J.; GLERUM, Chris and WEBB, Paul. Daylength, temperature and fertilization effects on desiccation resistance, cold hardiness and root growth potential of Picea mariana seedlings. Annals of Forest Science, 2003, vol. 60, p. 307-317.

CORREIA, M.J.; TORRES, F. and PEREIRA, J.S. Water and nutrient supply regimes and the water relations of juvenile leaves of Eucalyptus globulus. Tree Physiology, 1989, vol. 5, p. 459-471.

COSTA E. SILVA, F.; SHVALEVA, A.; MAROCO, J.P.; ALMEIDA, M.H.; CHAVES, M.M. and PEREIRA, J.S. Responses to water stress in two Eucalyptus globulus clones differing in drought tolerante. Tree Physiology, August 2004, vol. 24, p. 1165-1172.

CHAVES, M.M.; MAROCO, J.P. and PEREIRA, J.S. Understanding plant responses to drought - from genes to the whole plant. Functional Plant Biology, 2003, vol. 30, no. 3 , p. 239-264.

FUJIKAWA, S. and KURODA, K. Cryo-scanning electron microscopic study on freezing behaviour of xylem ray parenchyma cells in hardwood species. Micron, December 2000, vol. 31, no. 6, p. 669-686.

GINDABA, Jiregna; ROZANOV, Andrey and NEGASH, Legesse. Response of seedlings of two Eucalyptus and three deciduous tree species from Ethiopia to severe water stress. Forest Ecology and Management, November 2004, vol. 201, no. 1, p. 119-129.

GUARNASCHELLI, Ana Beatriz; LEMCOFF, Jorge Hugo; PRYSTUPA, Pablo and BASCI, Santiago. Responses to drought preconditioning in Eucalyptus globules Labill. provenances. Trees, November 2003, vol. 17 , no. 6 , p. 501-509.

GUARNASCHELLI, Ana Beatriz; PRYSTUPA, Pablo and LEMCOFF, Jorge Hugo. Drought conditioning improves water status, stomatal conductance and survival of Eucalyptus globules subsp. Bicostata seedlings. Annals of Forest Science, December 2006, vol. 63, no. 8, p. 941-950.

HSIAO, Theodore C. and XU, Liu-Kang. Sensitivity of growth of roots versus leaves to water stress: biophysical analysis and relation to water transport. Journal of Experimental Botany, September 2000, vol. 51, no. 350, p. 1595-1616.

KAUSHAL, Parvinder and AUSSENAC, Gilbert. Transplanting shock in Corsican pine and cedar of Atlas seedlings: internal water deficits, growth and root regeneration. Forest Ecology and Management, April 1989, vol. 27 , no. 1, p. 29-40.

LANDIS, Thomas D. Irrigation and water management. In: LANDIS, T.D.; TINUS, R.W.; MCDONALD, S.E. and BARNET, J.P. The container tree nursery manual. Agricultural Handbook. 647. Washington, D.C. U.S. Department of Agriculture, Forest Service. 1989, vol. 4, p. 69-118.

LARCHER, Walter. Physiological Plant Ecology: Ecophysiology and stress physiology of functional groups. $4^{\text {th }}$ ed. New York; Springer Press, 2003. 513 p. ISBN 9783540435167.

LEMCOFF, Jorge Hugo; GUARNASCHELLI, Ana Beatriz; GARAU, Ana and PRYSTUPA, Pablo. Elastic and osmotic adjustments in rooted cuttings of several clones of Eucalyptus camaldulensis Dehn. from southeastern Australia after a drought. Flora, November 2002, vol. 197, no. 2, p. 134-142.

MARRON, Nicolas; DREYER, Erwin; BOUDOURESQUE, Eric; DELAY, Didier; PETIT, JeanMichel; DELMOTTE, Francis and BRIGNOLAS, Franck. Impact of successive drought and re-watering cycles on growth and specific leaf area of two Populus x canadensis (Moench) clones, 'Dorskamp' and 'Luisa_Avanzo'. Tree Physiology, November 2003, vol. 23, p. 1225-1235.

MASON, E.G. A model of the juvenile growth and survival of Pinus radiata D. Don-Adding the effects of initial seedling diameter and plant handling. New Forests. September 2001, vol. 22, no. 1, p 133-158. 
MORAGA, P.; ESCOBAR, R. and VALENZUELA, S. Resistance to freezing in three Eucalyptus globulus Labill subspecies. Electronic Journal of Biotechnology [online]. 15 April 2006, vol. 9, no. 3 [cited 17 August 2007]. Available from Internet: http://www.ejbiotechnology.info/content/vol9/issue3/full/2 4/index.html. ISSN 0717-3458.

NGUGI, Michael R.; DOLEY, David; HUNT, Mark A.; DART, Peter and RYAN, Paul. Leaf water relations of Eucalyptus cloeziana and Eucalyptus argophloia in response to water deficit. Tree Physiology, March 2003, vol. 23, p. 335-343.

OSORIO, J.; OSORIO, M.L.; CHAVES, M.M. and PEREIRA, J.S. Water deficits are more important in delaying growth than in changing patterns of carbon allocation in Eucalyptus globulus. Tree Physiology, 1998, vol. 18 , p. 363-373.

PEARCE, Roger. S. Plant freezing and damage. Annals of Botany, April 2001, vol. 87, no. 4, p. 417-424.

PÉREZ, Juan; IRIGOYEN, Juan José and SÁNCHEZDÍAZ, Manuel. Chilling of drought-hardened and nonhardened plants of different chilling-sensitive maize lines changes in water relations and ABA contents. Plant Science, January 1997, vol. 122, no. 1, p. 71-79.

PIEPHO, H.P.; BÜCHSE A. and EMRICH, K.A. Hitchhiker's Guide to Mixed Models for Randomized Experiments. Journal of Agronomy \& Crop Science, 2003, vol. 189 , p. 310-322.

PITA, Pilar and PARDOS, José A. Growth, leaf morphology, water use and tissue water relations of Eucalyptus globulus clones in response to water deficit. Tree Physiology, 2001, vol. 21, p. 599-607.

REYES-DÍAZ, Marjorie; ALBERDI, Miren; PIPER, Fidra; BRAVO, León Aloys and CORCHERA, Luis Julián. Low temperature responses of Nothofagus dombeyi (Mirb.) Blume and Nothofagus nitida (Phil.) Krasser, two evergreen species from South Central Chile. Tree Physiology, August 2005, vol. 25, p. 1389-1398.

RITCHIE, G.A. and TANAKA, Y. Root growth potential and the target seedling. In: ROSEBURG, O.R.; ROSE, R.; CAMPBELL, S.J. and LANDIS, T.D. eds. Target Seedling Symposium: Proc. Meeting Western Forest Nursery Assoc., USDA Forest Service Gen. Tech Rept. RM-200, Fort Collins, CO. 1990, p. 37-52.

SHVALEVA, A.L.; COSTA E.; SILVA F.; BREIA, E.; JOUVE J.; HAUSMAN, J.F.; ALMEIDA, M.H.; MAROCO, J.P.; RODRIGUES, M.L.; PEREIRA, J.S. and CHAVES, M.M. Metabolic responses to water deficit in two Eucalyptus globulus clones with contrasting drought sensitivity. Tree Physiology, November 2005, vol. 26, p. 239-248.
SIMPSON, David G. and RITCHIE, Gary A. Does RGP predict field performance? A debate. New Forests, May 1997, vol. 13, no. 1, p. 253-277.

SOUTH, David B. and ZWOLINSKI, Janusz B. Transplant stress index: A proposed method of quantifying planting check. New Forests, May 1997, vol. 13, no. 1, p. 315-328.

TINUS, Richard. Root growth potential as an indicator of drought stress history. Tree Physiology, 1996, vol. 16, p. 795-799.

TYREE, M.T. and HAMMEL, H.T. The measurement of the turgor pressure and the water relations of plants by the pressure-bomb technique. Journal of Experimental Botany, 1972, vol. 23, p. 267-282.

VILLAR-SALVADOR, Pedro; PLANELLES, Rosa; OLIET, Juan; PEÑUELAS-RUBIRA, Juan L.; JACOBS, Douglas F. and GONZÁLES, Magdalena. Drought tolerante and transplanting performance of hola oak (Quercus ilex) seedlings after drought hardening in the nursery. Tree Physiology, August 2004, vol. 24, p. 11471155 .

WHITE, Don A.; TURNER, Neil C. and GALBRAITH, Jeffrey $H$. Leaf water relations and stomatal behavior of four allopatric Eucalyptus species planted in Mediterranean southwestern Australia. Tree Physiology, 2000, vol. 20, p. 1157-1165. 